\title{
DETERMINAN PERTUMBUHAN EKONOMI NEGARA OKI
}

\author{
Tamimah, Sri Herianingrum, Nur Rachmat Arifin \\ Program Magister Universitas Airlangga Surabaya \\ Jl. Airlangga No.4-6, Kota Surabaya \\ Email: tamimah-2018@pasca.unair.ac.id
}

Diterima: 16 November 2019; Direvisi: 18 Desember 2019; Diterbitkan: 19 Desember 2019

\begin{abstract}
Abstrak
Pertumbuhan ekonomi suatu negara menjadi tujuan awal dari pencapaian yang diharapkan oleh berbagai negara di dunia begitu juga dengan negara Organisasi Konferensi Islam (OKI). Terdapat berbagai indikator yang digunakan untuk melihat pertumbuhan ekonomi dan salah satunya adalah peningkatan Gross Domestic Produk. GDP merupakan total keseluruhan nilai produksi barang atapun jasa yang berada dalam suatu negara salama satu tahun. Penelitian ini bertujuan untuk melihat apa saja faktor-faktor yang mempengaruhi pertumbuhan ekonomi negara oki dengan ekspor, inflasi, dan nilai tukar sebagai variabel independen dan GDP sebagai variabel dependen. Metode yang digunakan dalam penelitian ini adalah Panel Vector Error Correction Model (PVECM) meliputi lima negara yakni Indonesia, Brunei Darussalam, Sudan, Bahrain, dan Malaysia selama kurun waktu 1985-2017. Hasil menunjukkna bahwa variabel ekspor, inflasi, dan nilai tukar memiliki pengaruh yang signifikan dalam jangka panjang maupun jangka pendek terhadap GDP. Variabel GDP lebih dominan memberikan kontribusi sebesar 90\%, ekspor memberikan kontribusi $6.1 \%$, inflasi memberikan kontribusi 2.8\%, dan variabel nilai tukar dengan kontribusi sebesar $0.02 \%$.
\end{abstract}

Kata Kunci: GDP, Ekspor, Inflasi, Nilai Tukar, Negara Oki.

\section{Abstract}

Economic growth of a country is the initial goal of the achievements expected by various countries in the world as well as the Organization of Islamic Conference (OIC) countries. There are various indicators used to see economic growth and one of them is an increase in Gross Domestic Products. GDP is the total value of all goods and services produced in a country for one year. This study aims to see what are the factors that influence the economic growth of the country with exports, inflation, and the exchange rate as an independent variable and GDP as the dependent variable. The method used in this study is the Panel Error Error Correction Model (PVECM) covering five countries namely Indonesia, Brunei Darussalam, Sudan, Bahrain, and Malaysia during the period 1985-2017. The results show that export, inflation and exchange rate variables have a significant long-term and short-term influence on GDP. The more dominant GDP variable contributed 90\%, exports contributed $6.1 \%$, inflation contributed $2.8 \%$, and the exchange rate variable contributed $0.02 \%$

Keyword: Gross Domestic Product, Exports, Inflation, Exchange Rates, Oki Countries.

\section{PENDAHULUAN}

Pertumbuhan ekonomi merupakan proses perubahan suatu perekonomian suatu negara secara berkesinambungan menuju waktu yang lebih baik dalam periode tertentu. Pertumbuhan ekonomi dapat diartikan sebagai proses kenaikan jumlah 


\section{Determinan Pertumbuhan Ekonomi \\ Negara OKI \\ Tamimah, Sri Herianingrum, Nur Rachmat Arifin \\ DOI: 10.24252/iqtisaduna.v5i2.11117}

produksi suatu perekonomian yang tercermin dari kenaikan pendapatan nasional (Jhingan, 2010). Keberhasilan pembangunan suatu negara dapat dilihat dari tingkat pertumbuhan ekonominya. Oleh sebab itu, setiap negara selalu menetapkan target tingkat pertumbuhan ekonomi yang stabil didalam perencanaan dan tujuan pembangunan negara. Pembuat kebijakan seperti pemerintah harus mengetahui strategi yang tepat untuk digunakan dalam mengatasi terjadinya resesi (Abdul , Shamshir, Hussain, \& Sabir, 2019).

Organisasi Kerjasama Islam atau OKI merupakan salah satu organisasi terbesar kedua setelah Perserikatan Bangsa - Bangsa (PBB) dari segi jumlah anggota. Saat ini OKI beranggotakan 57 negara yang mayoritas penduduknya beragama Islam. Organisasi Kerjasama Islam dibentuk pada tanggal 25 September 1969 yang memiliki tujuan awal untuk menjaga dan melindungi kepentingan umat Islam dalam mencapai perdamaian dunia. OKI juga ikut berkontribusi pada bidang ekonomi yang bertujuan untuk memperkuat kerjasama ekonomi dan perdagangan dalam rangka mencapai integrasi ekonomi global. Negara anggota OKI dikategorikan dalam empat kelompok besar berdasarkan.

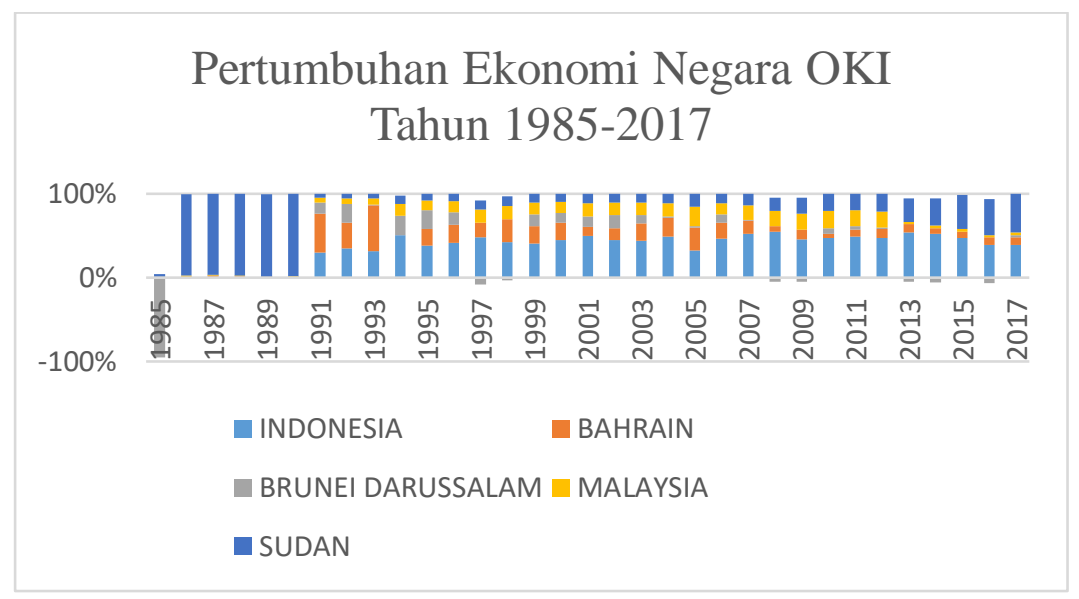

Sumber: (World Bank, 2018)

Pertumbuhan ekonomi merupakan keadaan ekonomi suatu negara selama periode tertentu dimana perkembangannya lebih baik atau meningkat dari periode sebelumnya yang bisa dilihat dari beberapa indikator, salah satunya adalah GDP. GDP adalah total keseluruhan nilai produksi barang atapun jasa yang berada dalam suatu negara salama satu tahun. Tingkat GDP negara Bahrain, Brunei Darussalam, dan Malaysia berada di atas tingkat GDP negara Indonesia dan Sudan.

Tingginya tingkat GDP di negara Bahrain, Brunei Darussalama, dan Malaysia menjadi pemicu bagi negara Indonesia dan Sudan untuk terus meningkatkan GDP 
negaranya agar dapat mewujudkan target-target yang sudah di canangkan. Mengingat bahwa GDP negara Indonesia dan Sudan masih berada dibawah negara Bahrain, Brunei Darussalam, dan Malaysia. Jika dibandingkan bahwa kelima negara tersebut berasal dari negara Islam namun apa yang menjadi latar belakang sehingga tingat GDP dari negara tersebut memiliki perbedaa. Sehingga dari penelitian ini ingin melihat apa saja yang menjadi faktor-faktor yang mempengaruhi pertumbuhan ekonomi negara dari kelima negara tersebut.

Terdapat berbagai penelitian yang dilalukan oleh penelitian sebelumnya untuk mengetahui pertumbuhan ekonomi negara oki (Prastity \& Cahyadin, 2013: Masi \& Sukamana, 2017: Indra, 2015). Namun dalam penelitian sebelumnya banyak meneliti tentang pertumbuhan ekonomi negara oki berdasarkan kategori peringkat negaranya, namun sangat jarang yang meneliti tentang perkembangan pertumbuhan negara oki berdasrakan dari dua kategori yakni negara maju dan berkembang. Sehingga penelitian ini ingin meneliti tentang analisis faktor-faktor yang mempengaruhi negara oki berdasarkan kategori negara maju dan berkembang pada periode sebelum dan sesudah krisis.

\section{TINJAUAN TEORITIK}

\section{Ekspor dan GDP}

Sektor ekspor memainkan peran utama dalam pembangunan ekonomi (Abdula \& Jaquet, 2002). Ekspor merupakan berbagai macam barang dan jasa yang telah di produksi didalam negeri dan dijual ke luar negeri (Puspitasari, 2014). Ekspor merupakan salah satu sumber dari asing yang digunakan sebagai pengurang terhadap pendapatan dan dapat menciptakan tenaga kerja dan meningkatkan pendapatan (Fannoun \& Hassouneh, 2019). Berbagai ekonom mengungkapkan bahwa peningkatan ekspor dapat meningkatkan pertumbuhan ekonomi karena ekspor merupakan salah satu unsur GDP (Md. Sazib Miyan \& Kabir Biplob, 2019).

Ekspor berpengaruh terhadap pertumbuhan ekonomi dilihat dari dua sisi, yakni dilihat dari sisi permintaan dan penawaran. Jika dari segi permintaan, apabila ketika sektor espor mempekerjakan sejumlah tenaga kerja, sehingga akan berpengaruh terhadap kekmampuan masyarakat dalam memperoleh pemasukan yang disebabkan oleh kemampuan perusahaan membayar upah terhadap tenaga kerja sehingga menajadikan rumah tangga untuk meningkatkan konsumsinya, namun dari 


\section{Determinan Pertumbuhan Ekonomi \\ Negara OKI \\ Tamimah, Sri Herianingrum, Nur Rachmat Arifin \\ DOI: 10.24252/iqtisaduna.v5i2.11117}

sisi pewanaran, ekspor dapat menjadi sumber pendanaan yang mendorong terhadap investasi. Insentif untuk meningkatkan investasi dan tekhnologi akan menyiratkan perbedaan produktivitas dalam mendukung sektor eskpror dengan kata lain produktivitas faktor marjinal diharapkan lebih tinggi dibandingkan sektor ekonomi lainnya (Sharma \& Panagiotidis , 2005).

Disisi lain juga dapat meningkatkan total produksi perusahaan (He \& Zhang, 2009). Penelitian menujukkan bahwa ekspor berpengaruh terhadap pertumbuhan ekonomi (Murindahabi, Qiang Li, Nisingizwe, \& Ekanayake, 2019:G. Dlamini \& V. Dlamini, 2019: Md. Sazib Miyan \& Kabir Biplob, 2019). Namun terdapat penelitian menunjukkan bahwa ekspor tidak memiliki pengaruh terhadap pertumbuhan ekonomi (Fakraoui \& Bakari, 2019: He \& Zhang, 2009).

H1. Ekspor berpengaruh terhadap Pertumbuhan Ekonomi

\section{Inflasi dan GDP}

Inflasi merupakan kenaikan harga secara terus menerus. Inflasi yang timbul karena permintaan akan barang-barang yang atau disebut juga dengan demand pull inflation (Nainggolan \& Aisyah , 2019). Inflasi disebabkan oleh adanya peningkatan permintaan agregat lebih cepat daripada penawaran sehingga dapat meningkatkan biaya barang dan jasa. Ketidakseimbangan permintaan dan penawaran secara agregat berkaitan dengan defisist pemerintah. Inflasi juga dapat meningkatkann harga barang dan tenaga kerja sehingga dapat meningkatkan harga jual dan harga pokok (Nurina, 2016).

Namun terdapat penelitian yang menyatakan bahwa inflasi tidak berpengaruh terhadap pertumbuhan ekonomi (Semuel \& Nurina, 2015). Bagi perekonomian inflasi yang tinggi dapat menyebabkan timbulnya ketidakstabilan ekonomi, menurunkan investasi, menghambat ekspor maupun dapat berdampak pada meningkatnya tingkat pengangguran. Dari sisi kesejahteraan, inflasi yang tinggi menyebabkan turunnya pendapatan riil masyarakat, terutama bagi pekerja-pekerja yang mempunyai penghasilan tetap, sehingga berdampak pada menurunnya tingkat konsumsi masyarakat dan meningkatkan kemiskinan (Rukmana, 2012). Semakin tinggi tingkat inflasi akan berdampak pada lebih rendahnya pertumbuhan ekonomi dan investasi (dalam rasio investasi terhadap GDP) dalam jangka panjang. Walaupun relatif kecil dampak negatif inflasi terhadap pertumbuhan ekonomi, namun dalam jangka panjang 
akan memberikan dampak yang cukup substantif terhadap kemakmuran masyarakat, sehingga inflasi yang tinggi perlu untuk ditanggulangi (Satria, 2012).

Inflasi merupakan salah satu indikator penting dalam perekonomian yang tidak bisa diabaikan, karena dapat menimbulkan dampak yang sangat luas baik terhadap perekonomian maupun kesejahteraan masyarakat. Oleh karena itu terdapat penelitian yang menyatakan bahwa inflasi berpengaruh terhadap pertumbuhan ekonomi suatu negara, semakin tinggi inflasi makan akan semakin melemahkan perekonomian suatu negara (Kasidi \& Mwakanemela, 2013: Sarel, 1996: He \& Zhang, 2009). Namun terdapat beberapa penelitian yang menunjukkan bahwa inflasi tidak berpengaruh terhadap pertumbuhan ekonomi (Burdekin \& Denzau, 2004:Semuel \& Nurina, 2015).

\section{H2. Inflasi berpengaruh terhadap Pertumbuhan Ekonomi}

\section{Nilai Tukar dan GDP}

Nilai tukar yang stabil dilihat sebagai tola ukur industri yang berhasil dalam suatu negara dan mampu meningkatkan pertumbuhan ekonomi. Pertumbuhan ekonomi yang tinggi dapat membantu mempertahankan tingkat cadangan devisa negara (Koirala, 2018). Nilai tukar mencerminkan keseimbangan permintaan dan penawaran terhadap mata uang dalam negeri maupun mata uang asing. Pertumbuhan ekonomi yang tinggi salah satunya didukung oleh pertumbuhan ekspor yang memadai sehingga meningkatkan nilai tukar, karena permintaan untuk mata uang nasional bertambah (Rudiawan \& Meirinaldi, 2019), nilai tukar yang baik akan membantu terhadap likuiditas pasar modal sehingga investor luar negeri juga akan bertambah (Guzman, Ocampo, \& Stiglitz, 2018). Namun merosotnya nilai tukar merefleksikan menurunnya permintaan masyarakat internasional terhadap mata uang karena menurunnya perekonomian nasional atau karena meningkatnya permintaan mata mata uang asing oleh masyarakat karena perannya sebagai alat pembayaran internasional.

Kegiatan pembiayaan ekspor dan impor membutuhkan suatu alat pembayaran yang sah dan berlaku secara internasional, bahkan dapat dikatakan kemampuan dan kondisi perekonomian suatu negara saat ini dapat ditentukan oleh adanya fluktuasi dari nilai tukar tersebut (Semuel \& Nurina, 2015). Selain itu nilai tukar antara mata uang suatu negara terhadap mata uang negara lainnya dapat berubah-ubah atau 
berfluktuasi (Susanto, 2018). Oleh karena itu nilai tukar dapat berpengaruh terhadap pertumbuhan ekonomi negara ( A Assery \& Peel, 1991: Siregar \& S. Rajan, 2004). Namun terdapat beberapa penelitian menujukkan bahwa nilai tukar tidak mempengaruhi terhadap peningkatan ekonomi negara (Willem Thorbecke, 2011:Iwayem \& Fowowe, 2010).

H3. Nilai Tukar berpengaruh terhadap Pertumbuhan Ekonomi

\section{METODE PENELITIAN}

\section{Jenis dan Sumber Data}

Jenis data yang digunakan dalam penelitian ini menggunakan data sekunder. Data pertumbuhan ekonomi dengan menggunakan GDP sebagai variabelnya yang terdiri dari 5 negara oki mulai tahun 1985-2017. Data ini diperoleh dari World Bank yang terdiri dari variabel Ekspor, Inflasi, dan Nilai Tukar definisi

\section{Definisi Operasional}

1) Pertumbuhan ekonomi merupakan keadaan ekonomi suatu negara selama periode tertentu yang mana lebih baik atau meningkat dari periode sebelumnya yang bisa dilihat dari beberapa indikator, salah satunya adalah GDP. GDP adalah total keseluruhan nilai produksi barang atapun jasa yang berada dalam suatu negara salama satu tahun

2) Ekspor merupakan suatu kegiatan perdagangan dimana barang dan jasa di dalam negeri dijual dan dikirimkan ke luar negeri dengan tujuan untuk memperoleh keuntungan.

3) Inflasi merupakan kenaikan harga secara umum dan terus menerus dalam jangka waktu tertentu. Kenaikan harga dari satu atau dua barang saja tidak dapat disebut inflasi kecuali bila kenaikan itu meluas (atau mengakibatkan kenaikan harga) pada barang lainnya (BPS , 2019)

4) Nilai Tukar merupakan nilai atau harga mata uang sebuah negara yang diukur atau dinyatakan dalam mata uang negara lain.

\section{Metode PVECM}


Vector Error Correction Model (VECM) merupakan bentuk Vector Auto Regression (VAR) yang memiliki batasan (retriksi) terkointegrasi atau terdapat hubungan jangka panjang antar variabel. VECM mengkombinasikan perilaku variabel dalam jangka panjang dan relasi antar variabel dalam jangka pendek. Oleh sebab itu, VECM mampu merefleksikan hubungan antar variabel dengan lebih baik. VECM biasanya dilakukan dalam data times series [6]. Pendekatan estimasi VECM dalam data panel dapat dilakukan dengan menggunakan framework berbasis likelihood untuk analisis kointegrasi pada Vector Error Correction Model dengan data panel lengkap (Baltagi \& Cao, 2000).

\section{HASIL DAN PEMBAHASAN}

Langkah pertama dalam melakukan analisis dalam penelitian ini adalah dengan melakukan pengujian terhadap metode data panel yang digunakan. Untuk menguji hal tersebut, dilakukan melalui Hausman Test.

Tabel 1. Hasil Uji Hausman

\begin{tabular}{llll}
\hline \hline Test Summary & Chi-Sq. Statistic & Chi-Sq. d.f.Prob. \\
\hline \hline Cross-section random & 5.838203 & 3 & 0.1198 \\
\hline \hline
\end{tabular}

Berdasarkan table diatas nilai prob. Chi Square $=0,1198>0,05$, maka $\mathrm{H}_{\mathrm{o}}$ diterima sehingga model yang dipilih Random Effect. Sehingga dapat disimpulkan bahwa dari uji Hausman model yang terbaik adalah Random Effect. Hasil data panel dengan Random Effect dapat dilihat dibawah ini

Cross-section random effects test equation:

Dependent Variable: GDP

Method: Panel Least Squares

Date: 10/28/19 Time: 22:19

Sample: 19852017

Periods included: 33

Cross-sections included: 5

Total panel (balanced) observations: 165

\begin{tabular}{crrrr}
\hline \hline Variable & Coefficient & Std. Error & t-Statistic & Prob. \\
\hline \hline C & -10.63817 & 16.53181 & -0.643497 & 0.5208 \\
EKS & 0.308375 & 0.095941 & 3.214207 & 0.0016 \\
INF & 0.017897 & 0.217673 & 0.082218 & 0.9346 \\
NT & -0.016826 & 0.090918 & -0.185073 & 0.8534 \\
\hline \hline
\end{tabular}


Cross-section fixed (dummy variables)

\begin{tabular}{lrlr}
\hline \hline R-squared & & & \\
Adjusted R-squared & 0.158920 & Mean dependent var & 20.74940 \\
S.E. of regression & 169.6372 & S.D. dependent var & 180.9799 \\
Sum squared resid & 4517954. & Schwarz criterion & 13.15247 \\
Log likelihood & -1077.079 & Hannan-Quinn criter. & 13.30306 \\
F-statistic & 4.237821 & Durbin-Watson stat & 13.21360 \\
Prob(F-statistic) & 0.000260 & & \\
& & &
\end{tabular}

Nilai koefisien Ekspor $=0.3083$, variable Ekspor mempunyai koefisien regresi yang positif terhadap GDP. Artinya apabila variable independen lainnya tetap, maka setiap kenaikan per satuan variabel Ekspor akan menyebabkan kenaikan GDP sebesar 0.3083 .

Nilai koefisien Inflasi $=0.0178$, variable Ekspor mempunyai koefisien regresi yang positif terhadap GDP. Artinya apabila variabel independen lainnya tetap, maka setiap kenaikan per satuan variabel Inflasi akan menyebabkan kenaikan GDP sebesar 0.0178 .

Nilai koefisien Nilai Tukar = -0.0168, variabel Ekspor mempunyai koefisien regresi yang negatif terhadap GDP. Artinya apabila variabel independen lainnya tetap, maka setiap kenaikan per satuan variabel Nilai Tukar akan menyebabkan kenaikan GDP sebesar -0.0168.

\section{Uji Stabilitas VAR}

Untuk menguji stabilitas atau tidaknya estimasi VAR yang telah dibentuk maka dilakukan pengecekan kondisi VAR stability berupa roots of characteristic polynominal. Suatu system VAR dilakukan stabil apabila seluruh rootsnya memiliki modulus lebih kecil dari satu (Gujarati, 2003).

Tabel 2. Uji Stabilitas VAR

\begin{tabular}{lcc}
\hline Model & Modulus & lag \\
\hline 0.845944 & 0.845944 & 2 \\
\hline
\end{tabular}

\section{Uji Lag Optimum}

Dalam menentukan lag optimum terdapat beberapa tahapan diantaranya: Pertama yaitu menentukan panjang lag maksimum sistem VAR yang stabil. Stabilitas sistem VAR dilihat dari inverse roots karakteristik AR polinomialnya. Suatu sistem VAR dikatakan stabil (stasioner) jika seluruh rootsnya memiliki modulus lebih kecil 


\section{Determinan Pertumbuhan Ekonomi \\ Negara OKI \\ Tamimah, Sri Herianingrum, Nur Rachmat Arifin \\ DOI: 10.24252/iqtisaduna.v5i2.11117}

dari satu dan semuanya terletak dalam unit circle. Kedua, panjang lag optimal akan dicari dengan menggunakan kriteria informasi Likehood Ratio (LR), Final Prediction Error (FPE), Akaike Information Critrion (AIC), Schwarz Information Critrion (SC) dan Hannan Quin Critrion (HQ). Panjang lag optimal diperlukan untuk menangkap pengaruh dari setiap variabel terhadap variabel lain di dalam sistem VAR. Lag optimal akan dipilih adalah lag yang paling banyak terpilih oleh beberapa uji kriteria yang digunakan tersebut, ditandai dengan tanda bintang (*) terbanyak pada lag tersebut (Badriyah, 2016). Berdasarkan hasil uji lag optimum lag dengan menggunakan kriteria Akaike Information Criterion (AIC), hasilnya menunjukkan menunjukan bahwa lag optimum pada lag 4 .

Tabel 3. Penentuan Lag Optimum

\begin{tabular}{ccccccc}
\hline Lag & LogL & LR & FPE & AIC & SC & HQ \\
\hline 0 & -3556.975 & NA & $2.52 \mathrm{e}+16$ & 49.11689 & 49.19901 & 49.15026 \\
\hline 1 & -3401.576 & 300.0794 & $3.68 \mathrm{e}+15$ & 47.19416 & $47.60474^{*}$ & 47.36099 \\
\hline 2 & -3366.599 & 65.61215 & $2.84 \mathrm{e}+15$ & 46.93241 & 47.67146 & 47.23271 \\
\hline 3 & -3345.315 & 38.75293 & $2.64 \mathrm{e}+15$ & 46.85951 & 47.92703 & 47.29328 \\
\hline 4 & -3300.113 & $79.80349^{*}$ & $1.77 \mathrm{e}+15^{*}$ & $46.45674^{*}$ & 47.85272 & $47.02397^{*}$ \\
\hline
\end{tabular}

\section{Uji Kointegrasi}

Uji kointegrasi dilakukan untuk mengetahui keberadaan hubungan antar variabel, khususnya dalam jangka panjang. Jika terdapat kointegrasi pada variabelvariabel yang digunakan di dalam model, maka dapat dipastikan adanya hubungan jangka panjang diantara variabel Apabila satu set variabel benar-benar terkointegrasi, maka harus dapat dideteksi implied restiriksi atau unrestriksi VAR. Berdasarkan hasil uji koingerasi, model ini terdapat kointegrasi pada taranf nyata 5\%.

Tabel 4. Uji Kointegrasi

\begin{tabular}{ccccc}
\hline Hypothesized & \multirow{2}{*}{ Eigenvalue } & Trace & 0.05 & \multirow{2}{*}{ Prob.* $^{*}$} \\
\cline { 1 - 1 } No. of CE(s) & & Statistic & Critical Value & \\
\hline None $^{*}$ & 0.592927 & 205.3380 & 47.85613 & 0.0000 \\
\hline At most 1 $^{*}$ & 0.282818 & 79.51128 & 29.79707 & 0.0000 \\
\hline At most 2 & 0.157346 & 32.97162 & 15.49471 & 0.0001 \\
\hline At most $3 *$ & 0.062289 & 9.003857 & 3.841466 & 0.0027 \\
\hline
\end{tabular}

\section{Hasil Empiris Estimasi Model VECM}

Hasil ini menunjukkan bahwa model pada pertumbuhan ekonomi negara oki telah memenuhi syarat untuk dapat di lanjutkan pada tahap uji estimasi VECM berdasarkan pada hasil uji kointegrasi yang telah dilakukan sebelumnya. Pada tahap uji estimasi VECM ini akan menjelaskan hubungan jangka pendek dan jangka panjang 
pada variabel-variabel penelitian. . Suatu variabel akan dikatakan signifikan dalam mempengaruhi variabel lain apabila nilai t-statistics dari variabel tersebut lebih besar daripada t- tabel pada taraf nyata $5 \%$ yaitu (t statistic $>1,65$ ) Hasil estimasi VECM pada Pertumbuhan ekonomi negara oki dapat dilihat pada table di bawah:

Tabel 5. Hasil Estimasi VECM

\begin{tabular}{ccc}
\hline & Long-term & \\
\hline Variables & coefficient & T statistic \\
\hline EKS(-1) & -1.268848 & {$[-6.66819]$} \\
\hline $\mathrm{INF}(-1)$ & 7.763145 & {$[\mathbf{6 . 0 1 9 6 4}]$} \\
\hline $\mathrm{NT}(-1)$ & -0.882527 & {$[-\mathbf{4 . 1 6 2 0 1 ]}$} \\
\hline & Short-term & {$[0.98522]$} \\
\hline $\mathrm{D}(\mathrm{EKS}(-1))$ & 0.061907 & {$[-\mathbf{2 . 1 6 7 1 5}]$} \\
\hline $\mathrm{D}(\mathrm{EKS}(-2))$ & -0.130416 & {$[\mathbf{2 . 9 1 1 9 9 ]}$} \\
\hline $\mathrm{D}(\mathrm{INF}(-1))$ & 0.866409 & {$[\mathbf{3 . 7 4 8 6 0}]$} \\
\hline $\mathrm{D}(\mathrm{INF}(-2))$ & 1.551971 & {$[-\mathbf{1 . 9 0 7 8 9}]$} \\
\hline $\mathrm{D}(\mathrm{NT}(-1))$ & -0.074578 & {$[-1.08304]$} \\
\hline $\mathrm{D}(\mathrm{NT}(-2))$ & -0.036907 &
\end{tabular}

Dalam estimasi VECM pada model pertumbuhan ekonomi negara oki, dijelaskan bahwa dalama jangka panjang semua variabel makroekonomi yakni ekspor, inflasi, dan nilai tukar berpengaruh secara signifikan terhadap GDP. Sedangkan dalam jangka pendek, variabel ekspor, inflasi, dan nilai tukar juga berpengaruh signifikan terhadap pertumbuhan ekonomi negara oki. Variabel ekspor berpengaruh secara signifikan terhadap GDP negara oki baik dalam jangka panjang maupun jangka pendek, hal itu didukung oleh penelitian (Hamdi , 2013: Ronit \& Divya, 2014) bahwa ekspor berkaitan dengan kemanjuan tekhnologi setiap tahunnya, peningkatan skala ekonomi yang berdampak terhadap perluasan ukuran pasar, dan mendorong efisiensi aolkasi daya saing ekspor perusahaan.

Jika perusahaan memiliki inisiatif untuk meningkatkan investasi dan meningkatkan tekhnologi, hal ini akan dapat meningkatkan dan mengembangkan produktivitas produksi sehingga mendorong sektor ekspor. Sehingga jika sektor ekspor berkembang dalam biaya sektor lain, maka akan berdampak terhadap output agregat (Abdula \& Jaquet, 2002). Variabel inflasi juga memiliki pengaruh yang signifikan dalam jangka panjang ataupun jangka pendek, hal ini sesuai dengan penelitian (Kasidi \& Mwakanemela, 2013) hal ini dinilai bahwa tingkat inflasi yang 
rendah tidak akan memiliki efek yang signifikan terhadap GDP, sehingga kenaikan inflasi yang rendah akan tetap menaikkan GDP negara oki (Chris \& Anyingang, 2012).

Disisi lain menghindari deflasi lebih diutamakan dibandingakan menghindari tingkat inflasi dalam negara (Burdekin \& Denzau, 2004). Sedangkan variabel nilai tukar juga memiliki pengaruh yang signifikan terhadap GDP negara oki dalam jangka panjang maupun jangka pendek menunjukkan bahwa di negara berkembang semakin tidak fleksibel sistem nilai tukar suatu negara, semakin rendah pula tingkat pertumbuhan ekonominya; sementara itu di negara maju tidak terlihat adanya perbedaan yang signifikan atas penggunaan sistem nilai tukar fixed dan floating (Eduardo \& Stuzenegger, 2003) dapat memberikan tingkat pertumbuhan ekonomi yang lebih tinggi, dalam hal ini tergantung pada preferensi dan kebijakan moneter yang menyertai rezim nilai tukar tersebut (Philippe \& Wincoop, 2000).

Sementara itu pengaruh nilai tukar terhadap pertumbuhan ekonomi melalui jalur AD bersifat contemporaneous, yakni terjadi segera setelah terjadinya perubahan nilai tukar tersebut. Beberapa komponen aggregate demand, seperti konsumsi, investasi, ekspor, dan impor, langsung bereaksi dan menuju ke nilai terbarunya. Perubahan besaran komponen-komponen $\mathrm{AD}$ tersebut menunjukkan terjadinya perubahan GDP dan pertumbuhan ekonomi.

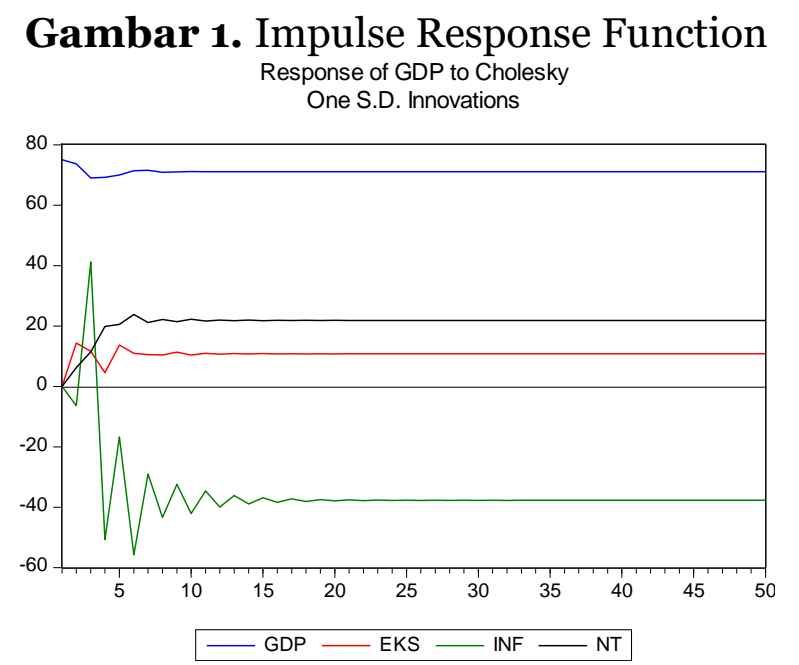

Analisis Impulse Response Function dilakukan untuk melihat jejak respon dari variabel dependen terhadap guncangan pada error terms dalam sistem VAR untuk beberapa periode kedepan. Gambar diatas menunjukkan bahwa hasil IRF dalam pertumbuhan ekonomi negara oki secara keseluruhan merespon negative ketika terjadi guncangan terhadap variabel Ekspor, Inflasi, dan Nilai Tukar. GDP merepson 


\section{Determinan Pertumbuhan Ekonomi \\ Negara OKI \\ Tamimah, Sri Herianingrum, Nur Rachmat Arifin \\ DOI: 10.24252/iqtisaduna.v5i2.11117}

positive pada periode pertama dan kembali stabil dalam period eke-5.Pada variabel ekspor mengalami guncangan pada arah positif dalam periode ke-2 dan kembali stabil dalam periode ke-3. Pada periode ke-2 inflasi merespon negative dan kembali merepson positif pada periode ke-3 dan kembali stabil pada periode ke-15. Sedangkan variabel nilai tukar merespon positif pada period eke- 5 dan kembali stabil pada periode ke-8.

\section{FEVD}

Setelah menganalisis perilaku guncangan melalui Impulse Response Function (IRF) maka tahap berikutnya adalah memprediksi kontribusi setiap variabel penelitian terhadap guncangan atau perubahan variabel tertentu dengan melihat model melalui Forecast Error Variance Decomposition (FEVD). Untuk memprediksi kontribusi guncangan masing-masing variabel Ekspor, Inflasi, dan Nilai Tukar terhadap pertumbuhan ekonomi

Gambar 2. Hasil FEVD

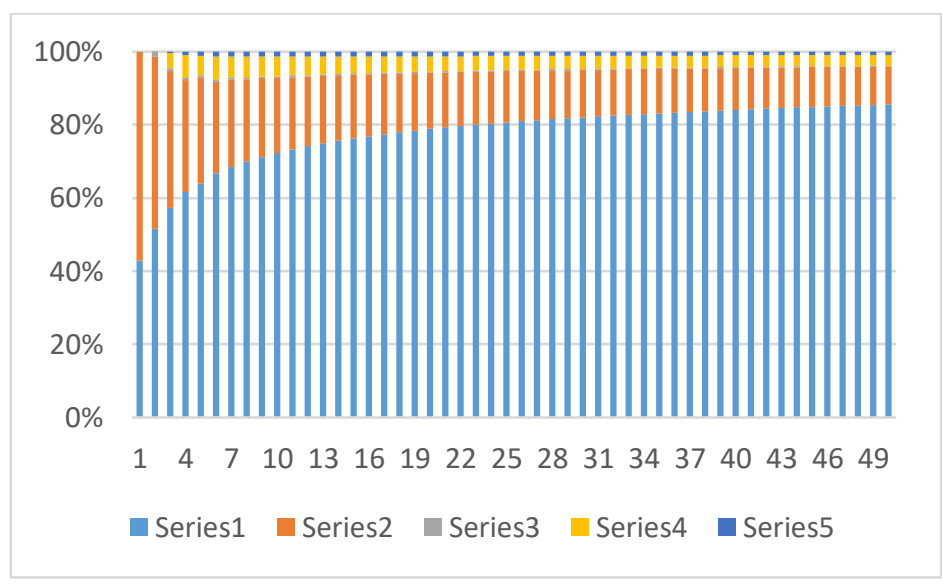

Gambar diatas menunjukkan bahwa GDP negara oki lebih dominan dipengaruhi oleh GDP itu sendiri dengan kontribusi sebesar 90\%. Dan dilanjutkan dengan ekspor yang memberikan kontribusi 6.1\%, inflasi memiliki kontibusi ketiga setelah ekspor dengan kontribusi 2.8\%. dan variabel yang memiliki kontribusi terendah diberikan oleh variabel nilai tukar dengan kontribusi sebesar $0.02 \%$ 


\begin{tabular}{ll}
\hline Gross Domestic Produk & $90 \%$ \\
\hline Ekspor & $6.1 \%$ \\
\hline Inflasi & $2.8 \%$ \\
\hline Nilai Tukar & $0.02 \%$
\end{tabular}

\section{KESIMPULAN}

Pertumbuhan ekonomi negara oki secara keseluruhan merespon negative ketika terjadi guncangan terhadap variabel Ekspor, Inflasi, dan Nilai Tukar. GDP merepson positive pada periode pertama dan kembali stabil dalam period eke-5. Pada variabel ekspor mengalami guncangan pada arah positif dalam periode ke-2 dan kembali stabil dalam periode ke-3. Pada periode ke-2 inflasi merespon negative dan kembali merepson positif pada periode ke-3 dan kembali stabil pada periode ke-15. Sedangkan variabel nilai tukar merespon positif pada period eke- 5 dan kembali stabil pada periode ke-8. Variabel GDP negara oki lebih dominan dipengaruhi oleh GDP itu sendiri dengan kontribusi sebesar 90\%. Dan dilanjutkan dengan ekspor yang memberikan kontribusi 6.1\%, inflasi memiliki kontibusi ketiga setelah ekspor dengan kontribusi $2.8 \%$. dan variabel yang memiliki kontribusi terendah diberikan oleh variabel nilai tukar dengan kontribusi sebesar 0.02\%.

\section{DAFTAR PUSTAKA}

A Assery , \& Peel. (1991). The Effects of Exchange Rate Volatility on Exports. Economics Letters, 173-177.

Iwayem, A., \& Fowowe, B. (2010). Impact of Oil Price Shocks on Selected Macroeconomic Variables in Nigeria. Energy Policy, 603-612.

Abdul , N. R., Shamshir, M., Hussain, A., \& Sabir, S. (2019). Relationship Between Major Macroeconomic Variables and Economic Growth: A case of Pakistan during 1976-2016. WALIA journal, 21-26.

Abdula, A., \& Jaquet, P. (2002). Exports and Economic Growth: Cointegration and Causality Evidence for Co`te d'Ivoire. African Development Bank, 1-17.

Badriyah, S. (2016). Pengaruh belanja Daerah terhadap PDRB Jawa Tengah Menggunakan Panel Vector Correction Model (PVECM). 171-178.

Baltagi , \& Cao. (2000). Nonstationary Panels, Cointegration in Panels and Dynamic Panels: A Survey. Surface Syracuse University.

BPS . (2019). Pengenalan Inflasi. Retrieved from bps.go.id

Burdekin, R., \& Denzau, A. (2004). When does Inflation Hurt Economic Growth? Different nonlinearities for ifferent economies. Journal of Macroeconomics, 519-532. 
Chris, U., \& Anyingang. (2012). The Effect of Interest Rate Fluctuation on the Economic Growth of Nigeria. International Journal of Business and Social Science, 1970-2010.

Eduardo, L. Y., \& Stuzenegger, F. (2003). To Float or to Fix: Evidence on the Impact of Exchange Rate Regimes on Growth . The American Economic Review, 11731193.

Fakraoui, N., \& Bakari, S. (2019). The Among Domestic Investment, Exports and Economic Growth: Empirical Analysis from India. Journal of Smart Economic Growth , 1-15.

Fannoun, Z., \& Hassouneh, I. (2019). The Causal Relationship between Exports, Imports and Economic Growth in Palestine. Journal of Reviews on Global Economics, 258-268.

G. Dlamini, S., \& V. Dlamini, D. (2019). Granger-causality Between Economic Growth and Sugar Exports in the Kingdom of Eswatini: A Toda-Yamamoto Approach. Journal of Agricultural Economics and Rural Development, 543-547.

Gujarati. (2003). Econometrika Dasar. Jakarta : Green William.

Guzman, M., Ocampo, J. A., \& Stiglitz, J. (2018). Real Exchange Rate Policies for Economic Development . World Development, 51-62.

Hamdi . (2013). Testing Export-led Growth in Tunisia and Morocco: New Evidence using the Toda and Yamamoto Procedure . Economics Bulletin, 677-686.

He, D., \& Zhang, W. (2009). How Dependent is the Chinese Economy on Exports and in What Sense has its Growth been Export-Led? Journal of Asian Economics, 87-104.

Indra, I. (2015). Analisis Faktor-Faktor yang Memengaruhi Tingkat Pertumbuhan Ekonomi pada 20 Negara OKI Tahun 2009-2013. Ekonomi dan perbankan Syariah, 11-21.

Jhingan. (2010). Ekonomi Pembangunan dan Perencanaan. Jakarta: Geafindo Persada.

Kasidi, F., \& Mwakanemela, K. (2013). Impact of Inflation on Economic Growth: A cash Study of Tanzania. Asian Journal of Empirical Research, 363-380.

Kasidi, F., \& Mwakanemela, K. (2013). Impact of Inflation on Economic Growth: A Cash Study of Tanzania. Asian Journal of Empirical Research, 363-380.

Koirala, S. (2018). An Analysis of the Impact of Real Effective Exchange Rate on Economic Growth of Nepal . Nepal Journals Online , 206-216.

Masi, \& Sukamana, R. (2017). Determinan Tingkat Pengangguran di Negara-Negara Organisasi Kerjasama Islam (OKI) dan Negara-Negara Non OKI di Asia Tenggara Periode Tahun 1985-2014. Jurnal Ekonomi Syariah Teori dan Praktik, 6-12.

Md. Sazib Miyan, \& Kabir Biplob, M. (2019). Revisiting Exports, Imports and Economic Growth Nexus: Empirical Evidence from Bangladesh (1981-2017). Modern Economy, 523-536. 
Murindahabi, T., Qiang Li, Nisingizwe, E., \& Ekanayake. (2019). Do coffee Exports Have Impact on long-term Economic Growth of Countries? Czech Academy of Agricultural Science.

Nainggolan, D. S., \& Aisyah , S. (2019). Peranan Kebijakan Moneter Mengendalikan Suku Bunga dan Inflasi serta Pengaruhnya terhadap Pertumbuhan Ekonomi di 4 Negara Asia (Singapura, Korea Selatan, dan Indonesia). Seminar Nasional \& Call For Paper Seminar Bisnis Magister Manajemen, 244-257.

Nurina, S. (2016). Analisis Pengaruh Inflation, Interest Rate, dan Exchange Rate Terhadap Gross Domestic Product (GDP) di Indonesia. Petra Business \& Management Review , 48-58.

Philippe, B., \& Wincoop. (2000). Does Exchange-Rate Stability Increase Trade and Welfare? . The American Economic Review, 1093-1109.

Prastity, N., \& Cahyadin, M. (2013). The Effect Foreign Direct Invesment and Trade Openness on Economic Growth in Organisation of Islmic Confrence (OIC) Member Countries in 2000-2013. Kajian, 255-270.

Puspitasari, G. (2014). The Effect of Gross Domestic Produc (GDP) and Exchange Rate of Major Trading Partners on Indonesia Natural Rubber Export 2000-2012. Kajian, 21-31.

Ronit, \& Divya. (2014). The Relationship Between the Growth of Exports and Erowth of GDP of India. International Journal of Business and Economics Research, 135-139.

Rudiawan, H., \& Meirinaldi. (2019). Dampak Faktor-Faktor Makro Ekonomi Terhadap Pertumbuhan Produk Domestik Bruto Indonesia . Jurnal Ekonomi, $1-15$.

Rukmana, I. (2012). Pengaruh Disparitas Pendapatan, Jumlah Penduduk dan Inflasi Terhadap pertumbuhan Ekonomi di Jawa Tengah. Economics Development Analysis Journal, 26-34.

Sarel, M. (1996). Nonlinear Effects of Inflation on Economic Growth . International Monetary Fund , 199-299.

Satria, D. (2012). Analisis Dampak Inflasi terhadap Pertumbuhan Ekonomi. 1-24.

Semuel , H., \& Nurina, S. (2015). Analysis of the Effect of Inflation, Interest Rates, and Exchange Rates on Gross Domestic Product (GDP) in Indonesia. Proceedings of the International Conference on Global Business, Economics, Finance and Social Sciences, 1-15.

Sharma, A., \& Panagiotidis , T. (2005). An Analysis of Exports and Growth in India: Cointegration and Causality Evidence (1971-2001). Review of Development Economics, 232-248.

Siregar , R., \& S. Rajan, R. (2004). Impact of Exchange Rate Volatility on Indonesia's trade performance in the 1990. Journal Japanese International Economies, 218-240.

Susanto. (2018). Pengaruh Inflasi, Tingkat Suku Bunga, dan Nilai Tukar terhadap Pertumbuhan Ekonomi Indonesia. Jurnal STIEBEI, 1-16. 
Willem Thorbecke. (2011). Investigating the Effect of Exchange Rate Changes on China's Processed Exports. Journal of The Japanese and International Economies, 33-46.

World Bank . (2018). Retrieved from worldbank.go.id 